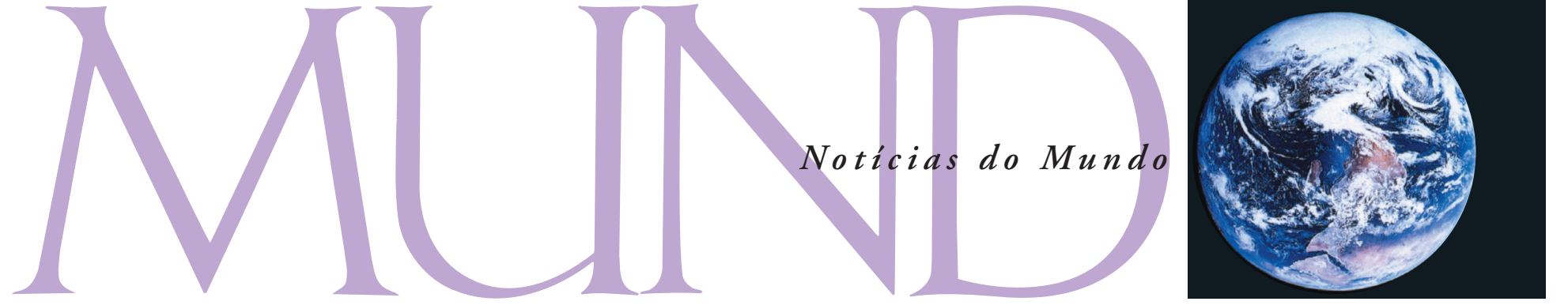

Tecnologia da informação

\section{Serviços alternativos de transporte $e$ locação de imóveis aumentam opções de consumo}

Na década de 1930, a cidade de Nova York criou a obrigatoriedade de licenças para taxistas. Cerca de 12 mil licenças foram expedidas. Em 2010, a cidade era 1 milhão de habitantes maior, mas o número de licenças cresceu pouco - para 13 mil. Durante 80 anos, a oferta de táxis não cresceu como a demanda.

Esse descompasso entre demanda e oferta, visível nas ruas, fez com que muitos habitantes passassem a oferecer o serviço com seus próprios carros por meio do aplicativo Uber, criado em 2009. O Uber não diz que faz o serviço de táxi, mas a similaridade é grande. Em pouco tempo, o número de carros com esse serviço praticamente dobrou, chegando a 25 mil.

Os taxistas sentiram no bolso o aumento da oferta, já que encontrar passageiros ficou mais difícil. O dono da maior cooperativa de táxi da cidade, com mais de 860 licenças, assinou um pedido de falência. Em 2015, em cidades como Rio de Janeiro, São Paulo, Londres e outras houve protestos, alguns violentos, de taxistas contra o aplicativo.
Para os passageiros, o Uber ajuda a encontrar transporte a um preço mais acessível. Por meio do aplicativo, eles podem ler pequenos comentários sobre motoristas específicos e, assim, contratar quem oferece um serviço de qualidade.

"É impossível que os taxistas e donos de cooperativas de táxi proíbam o Uber para sempre", afirma o economista e professor da Fundação Getúlio Vargas Roberto Kanter. "O que pode acontecer são as cooperativas passarem a ter um serviço melhor, com maior qualidade, e assim conseguirem manter uma fatia desses consumidores", explica.

Dentre os grupos que ganham com o Uber e serviços similares estão os que investiram para que o aplicativo fosse desenvolvido e funcionasse bem. Entre eles, estão o Google, o site de busca chinês Baidu e o banco de investimentos Goldman Sachs. A cada corrida realizada por meio do aplicativo, uma parte do pagamento vai para esses investidores. Na prática, portanto, o Uber transfere dinheiro dos donos das cooperativas de táxis para os investidores da plataforma, grandes conglomerados que têm negócios em diversas áreas da economia.

"O investidor está atrás de rentabilidade", diz Kanter. "Eles apostam em uma inovação, e quem não inova, no caso os proprietários de cooperativas, tende a perder dinheiro". $\mathrm{O}$ mesmo se passa com o AirBNB, um site e aplicativo por meio do qual é possível alugar apartamentos ou quartos em outras cidades por um preço mais em conta do que em hotéis. Criado em agosto de 2008, o AirBNB foi inspirado no site CouchSurfing, no qual é possível conseguir um lugar para dormir em diversas cidades sem ter que pagar por isso. Apesar da gratuidade da estadia, o site também é bancado por grandes investidores e não é uma organização sem fins lucrativos.

Apesar de alguns protestos dos proprietários de redes hoteleiras em função de seu surgimento, como a Associação Brasileira da Indústria de Hotéis (Abih), a repercussão esteve longe de ser tão violenta como a dos taxistas em relação ao Uber. A razão talvez seja que o impacto do AirBNB sobre os hotéis foi muito menor do que o ocorrido no mercado dos táxis. O AirBNB tem hoje cerca de um milhão de quartos e apartamentos para serem alugados em diversos países. O número de quartos de hotéis no mundo é de 21 milhões.

De acordo com artigo da socióloga norte-americana Juliet Schor de 2015, "o único ponto novo dessa nova economia do compartilhamento é que ela mobiliza a tecnologia, os mercados e a 'sabedoria das multidões' para fazer com que estranhos se encontrem". 